\title{
Copyrights: Everything you need to Know
}

\section{Konstantinos Tzikas*}

Attorney at Law firm Tzikas and Partners-accredited mediator, Greece

\begin{abstract}
This article is a brief guide, in accordance with Greek Law 2121/1993, in line with the directives of the European Community, copyright, related rights and cultural issues, and after the last modification N.4242/2013, what need to know and how to protect someone / s who created spiritual work, what is the object of the protection of intellectual property, how many years is protected under the law the right to intellectual property and what are the civil and criminal penalties for this that infringes the copyright of the author.
\end{abstract}

\section{What is the Spiritual Creation and Copyright?}

Intellectual creation as we all know everything is original from the creator of such works of literature, books, works of art (paintings) photography, music (composition and lyrics), songs, theater, trademarks and software or databases. The intellectual property rights existing in these projects and protect their creator for some time, prohibiting others from using the above works without the prior permission of the creator.

\section{Copyright}

According to Article 1, paragraph 1, rightholders with the creation of the work, acquire onto it Intellectual property, including, as exclusive and absolute rights, the right to exploit the work (property rights) and the right to protection personnel to link to it (Moral rights).

\section{Object of the Right}

In accordance with Article $2 \S 1$ as regards the subject- reported including the following: as a work means any original intellectual creation of speech, art or science, expressed in any form, including written or oral texts, musical compositions, with or without text, plays, with or without music, choreography and pantomimes, audiovisual works, works of fine art, including drawings, paintings and sculptures, engravings and lithographs, architectural works, photographs, works of applied art, illustrations, maps, three-dimensional works relative to geography, topography, architecture or science.

The Act also provides the what: "2.a. Object protection is and databases which, by reason of the selection or arrangement of their contents constitute intellectual creations.

This protection does not extend to the content of databases and without prejudice to any rights subsisting in the contents. As database means a collection of works, data or other materials arranged in a systematic or methodical way and individually accessible by electronic or otherwise. “

\section{Computer Programs}

In this Act makes specific reference to computer programs and the preparatory design material which is considered as literary works and subject to the provisions of Chapter 7 of this law, protected by the copyright law. The law also provides that a computer program is considered original if it is personal brainchild of creator.

\section{The Property Rights}

According to Article 3 Fri 1 provides that the property rights give authors notably the (right) to authorize or prohibit: a) The registration and the direct or indirect, temporary or permanent reproduction

Their works by any means and in any form, in whole or in part.

b) The translation of their works.

c) The arrangement, adjustment or other alterations of their works.

d) In respect of the original or copies ( replicas ) of their works, the Distribution to the public in any form by sale or other Ways. The distribution right within the Community exhausted only if the First sale or otherwise of the first Transfer Ownership of the original or copies in the Community made by the rightholder or with his consent.

Also mention including the rental and public lending of the original or copies of their works. The rental and public lending means in accordance with the provisions of Directive 92/100 of 19 November 1992 (OJ No. I 346/61, 27.11.1992).

In addition, the creator can allow or bans import of copies of their works produced abroad without the consent of the author or, in the case of imports from countries outside the European Community, whether the right of import in Greece had been retained by the Developer. (Articles 2, $3 \S 1$ and 3, 4 0digias 2001/29 OJ No. L.167/10 22.6.2001)."

\section{Type of License, Restrictions and Rights During}

In Article 52 of this Law referred to all those types of licenses that are protected under the copyright law and what are the limitations and the duration of copyright protection. Specifically mentioned among others the following: the rights provided in articles 46 to 51 (Permission of performers, producers of materials license operators, licensed by broadcasters right to equitable remuneration, moral rights, publishers) are governed by the following rules: a) transactions relating these rights apply only if made in writing ' b) the restrictions provided for" the property rights of intellectual property, "and accordingly apply for these'.

*Corresponding author: Konstantinos Tzikas, Attorney at Law Firm Tzikas and Partners-Accredited Mediator, Greece, Tel: 302310266849; E-mail: konstantinostzikas@gmail.com

Received May 13, 2014; Accepted January 22, 2015; Published January 30, 2015

Citation: Tzikas K (2015) Copyrights: Everything you need to Know. Intel Prop Rights 3: 137. doi:10.4172/2375-4516.1000137

Copyright: ( 2015 Tzikas K. This is an open-access article distributed under the terms of the Creative Commons Attribution License, which permits unrestricted use, distribution, and reproduction in any medium, provided the original author and source are credited. 


\section{Duration of Copyright Protection from 50 Years to 70}

According to the relevant provision of the law, the duration of the rights of performers provided for in Articles 46 and 49 of this law shall expire fifty (50) years after the date of the performance, but cannot be less than the lifetime of the artist.

Also reference is made inter alia for the duration of the rights of phonogram producers (producers of sound) which expire fifty years after the fixation is made. However, if the phonogram has been lawfully published during this period, the rights shall expire ' seventy ' years from the date of the first lawful publication etc.

Within fifty (50) years is also the term of protection of rights: the producers of audiovisual works (producers of video or audio and video), broadcasters under Article 48, the right of issuers referred to in Article 51 and others.

\section{Injunctions Against Attack}

According to Article 64 paragraph 1, the law provides, inter alia, the following regarding how to protect the creator of the insult exists in spiritual rights: If alleged infringement of copyright or related rights referred to in Articles 46 to 48 and 51 or the sui generis right of a database maker, the First Instance Court ordered as a precautionary measure seizure of objects held by the defendant 'constitute means of committing or product or evidence of infestation. Instead of garnishment, the court may order the detailed inventory of such items, including photographing them. In the above cases applies compulsorily Article 687 Fri the 1st Civil Procedure Code and mandatory injunction granted under Article 691 Fri the 2nd Civil Procedure Code. (Article 7 of Directive 2004/48).

Also in accordance with paragraph 2 of this Article, the court order or injunction preserving evidence without needing to identify specific projects, threatened with attack or attacked.

However if the above injunction in accordance with paragraph 7 of this article revoked due to any act or omission by the applicant, or where it is subsequently found that there has been no infringement or threat of infringement of the rights of this Act, the court may order the applicant, if acted improperly, upon request of the defendant ' th, to provide the defendant 'th appropriate compensation for any injury caused by these measures. "(Articles 7 and 9 of Directive 2004/48).

\section{Civil Penalties}

According to Article 65 paragraph 1, in each case of infringement or threatened infringement of copyright or related rights the creator or owner of rights related to copyright can be claimed in the case of the recognition of its right to waive the breach and failure future. The removal of infestation can include as 'application of the plaintiff limited to: a) the withdrawal of trade goods found to be infringing the right of this Act and, if necessary, material principally used in the creation or manufacture of those goods b) a permanent removal of such trade or c) their destruction. The rights of the first subparagraph of this paragraph are the beneficiaries and intermediary whose services are used by third parties for infringing this law".

\section{Imprisonment up to 10 Years}

Finally, according to Article 66 of this Act provides that a person without right and in violation of the provisions of this Act or provisions of law certified by multilateral international conventions for the protection of copyright of a work or copies, reproduces them directly or indirectly, temporarily or permanently in any form, in whole or in part, translate, adapts or converts them, makes a distribution to the public by sale or other means, etc. is punishable by one year's imprisonment and a fine of 2,900 to 15,000 euros.

If the benefit sought or threatened harm by the acts of paragraphs 1 and 2 is very large, it is at least two years' imprisonment and a fine of 2-10 million drachmas. If the culprit is the aforementioned acts by 'occupation 'or on a commercial scale" or whether the circumstances under which the act was testified that the perpetrator is particularly dangerous for the protection of copyright or related rights, Imprisonment up to 10 years and a fine of 5-20 million drachmas, and remove the license of the enterprise in which the act was performed.

* $\mathrm{O}$ Mr Tzikas is a lawyer and certified mediator by the Ministry of Justice Transparency and Human Rights. 